\title{
Analisis Total Quality Management (TQM) Dalam Manajemen Operasional di Intanaya Tour and Travel Cabang Surabaya
}

\author{
Imas Maesaroh, Siska Purnama \\ Universitas Islam Negeri Sunan Ampel Surabaya \\ imas.kholis@gmail.com
}

\begin{tabular}{l}
\hline \hline Article Info \\
\hline Keyword: \\
Total Quality \\
Management (TQM), \\
Manajemen Operasional, \\
Intanaya Tour and Travel
\end{tabular}

Page: $43-54$

\section{Editorial Office:}

Program Studi Manajemen Dakwah, Fakultas Dakwah dan Komunikasi, UIN Sunan Ampel Surabaya. Jl. Ahmad Yani 117 Surabaya, Jawa Timur, Indonesia.

Email: jurnalilkom@uinsby.ac.id

This study is to determine and analyze the concept of Total Quality Management and its implementation in the Surabaya Branch of Intanaya Tour and Travel. Researchers used descriptive qualitative methods. The results of the study illustrate that the concept of Total Quality Management in Intanaya Tour and Travel is a customer value strategy in the form of a questionnaire strategy and business planning in congregational mapping. Secondly, an organizational system in the form of employees who focus on providing customer value, a communication system that upholds service quality and a leader control system for employees. Thirdly, quality improvement at Intanaya Tour and Travel in the form of planning by the manager. The implementation of Total Quality Management at Intanaya Tour and Travel has three phases: preparation, planning and implementation. It includes an operational manager who focuses on quality control, the application of PDCA (Plan-Do-Check-Adjust) activities in the quality control system and an evaluation system for employees and congregational services.

Penelitian ini adalah untuk mengetahui dan menganalisis konsep Total Quality Management dan implementasinya di Intanaya Tour and Travel Cabang Surabaya. Peneliti menggunakan metode penelitian kualitatif deskriptif. Hasil penelitian menggambarkan bahwa konsep Total Quality Management di Intanaya Tour and Travel, yang pertama, adalah strategi nilai pelanggan berupa strategi kuisioner serta perencanaan bisnis dalam pemetaan jamaah. Kedua, sistem organisasional berupa adanya karyawan yang fokus pada penyediaan nilai pelanggan, sistem komunikasi yang menjunjung kualitas pelayanan serta sistem kontrol pemimpin kepada karyawan. Ketiga, perbaikan kualitas di Intanaya Tour and Travel berupa perencanaan oleh manajer. Implementasi Total Quality Management di Intanaya Tour and Travel mempunyai tiga fase: persiapan, perencanaan dan pelaksanaan. Di dalamnya mencakup adanya manajer operasional yang fokus untuk mengontrol kualitas, adanya kegiatan PDCA (Plan-DoCheck-Adjust) dalam sistem control kualitas serta adanya sistem evaluasi terhadap karyawan dan pelayanan jamaah.

$$
\text { Email: jurnalilkom@uinsby.acid }
$$




\section{Pendahuluan}

Persaingan ekonomi dunia semakin ketat, menuntut kepiawaian manajemen untuk mengantisipasi setiap perubahan yang terjadi dalam aktivitas ekonomi dunia (Ariani, 2003). ${ }^{1}$ Kondisi ini mendorong organisasi atau perusahaan untuk meningkatkan kepuasan pelanggan melalui jaminan kualitas produk atau jasa yang ditawarkan. Kualitas digunakan untuk mencapai tujuan dan memperoleh keunggulan kompetitif (Gaspersz, 1998). ${ }^{2}$ Secara operasional, mutu atau kualitas ditentukan oleh dua faktor, yaitu terpenuhinya spesifikasi yang telah ditentukan sebelumnya dan terpenuhinya spesifikasi yang diharapakan menurut tuntutan dan kebutuhan pelanggan (Sallis, 2006). ${ }^{3}$ Untuk mewujudkan kualitas dan kepuasan pelanggan tersebut, perusahaan membutuhkan system manajemen berbasis kualitas, yaitu total quality management.

Total quality management digunakan untuk memaksimumkan daya saing organisasi melalui perbaikan secara terusmenerus atas produk, jasa, sumber daya manusia, maupun lingkungan organisasinya. Total quality management melakukan perbaikan di semua lini baik dalam pelayanan, manajemen keuangan, pemasaran, hingga sumber daya manusia di organisasi (Suyitno, 2016). ${ }^{4}$ Kepuasan konsumen menjadi pusat berhatian dan ia diciptakan melalui kualitas pelayanan dan

\footnotetext{
${ }^{1}$ Ariani, Dorothea Wahyu, Manajemen Kualitas Pendekatan Sisi Kualitati, (Jakarta : Ghalia Indonesia, 2003), hal. 6

${ }^{2}$ Gaspersz, Manajemen Produktivitas Total, (Jakarta : Gramedia Pustaka Utama, 1998), hal. 177
}

nilai. Tidak terkecuali perusahaan di bidang tour dan travel.

Intanaya Tour and Travel adalah salah satu perusahaan yang menerapkan total quality management. Hal ini terbukti dari adanya kepuasan pelanggan di Intanaya Tour and Travel dan peningkatan jamaah setiap tahunnya. Berdiri di Surabaya sejak tahun 2015 dengan brand "Siap melayani para Tamu Allah", Intanaya Tour and Travel mempunyai cabang kantor yang tersebar di Jawa Timur dan Jawa Tengah. Total pemberangkatan mulai 2015 sampai sekarang mencapai 5200 jamaah. Dari segi prosesnya, Intanaya Tour and Travel mempunyai sistem perbaikan di aspek produk, dimulai dari harga, bentuk pelayanan serta tingkat variasi produk yang ditawarkan. Pada aspek SDM, Intanaya Tour and Travel juga mengarah ke pelayanan kualitas terhadap kepuasan konsumen melalui sikap dan pelayanan yang ramah dan menyenangkan, serta pelayanan pasca umroh berupa menjalin silaturrahim dengan jamaah.

Mengingat pentingnya total quality management dalam rangka pengembangan perusahaan Tour and Travel, fenomena Intanaya Tour and Travel menarik perhatian peneliti untuk mengkaji di dalamnya. Fokus penelitian ini adalah menjawab bagaimana konsep dan implementasi total quality management dalam manajemen operasional di Intanaya

3 Edward Sallis, Total Quality Management in Education; Manajemen Mutu Pendidikan, (Yogyakarta : IRCiSoD, Cet. IV, 2006) hal. 7

${ }^{4}$ Suyitno, Peningkatan Sumber Daya Manusia Melalui Penerapan Total Quality Management, (Jurnal Akuntansi, Ekonomi, dan Manajemen Bisnis, Vol.4, No.2, 2016), hal. 150-157 
Tour and Travel. Tujuan penelitian ini adalah mengetahui konsep dan implementasi total quality management dalam manajemen operasional di Intanaya Tour and Travel. Dengan penelitian ini diharapkan dapat memotivasi perusahaan travel lainnya untuk memberikan kinerja terbaiknya demi keberlangsungan perusahaan di masa mendatang.

\section{Kajian Pustaka}

\section{Mutu (Quality)}

Mutu atau kualitas diartikan sebagai standar minimal suatu produk atau jasa. Setiap orang memiliki persepsi kualitas yang berbeda-beda. Tolak ukur kebaikan suatu produk atau jasa terdiri dari kualitas desain dan kualitas kesesuaian. Kualitas desain menggambarkan fungsi spesifikasi produk atau jasa yang diproduksi suatu perusahaan. Kesesuaian kualitas dapat dilihat dari ukuran produk atau jasa dalam memenuhi persyaratan atau spesifikasi kualitas yang telah ditetapkan (Tjiptono \& Diana, 2002). Setidaknya ada empat perspektif terkait kualitas, yakni kesesuaian dengan persyaratan/standart yang telah ditentukan, kesesuaian dengan kebutuhan pasar, kepuasan pelanggan sepenuhnya, serta keadaan dinamis yang memenuhi atau melebihi harapan pelanggan atau konsumen (Nasution, 2015).

Pentingnya kualitas dibedakan menjadi dua sudut pandang: manajemen operasional dan manajemen pemasaran. Berdasarkan sudut pandang manajemen operasional, kualitas produk adalah salah satu keputusan penting dalam meningkatkan daya saing produk. Sedangkan dari sudut manajemen pemasaran, kualitas produk adalah salah satu unsur penting dari bauran pemasaran meliputi produk, harga, promosi, dan saluran distribusi. Empat elemen tersebut dapat meningkatkan volume penjualan dan memperluas pangsa pasar perusahaan (Nasution, 2015).

\section{Total Quality Management}

Total quality management adalah pendekatan dalam menjalankan usaha yang mencoba untuk memaksimumkan daya saing organisasi melalui perbaikan terus menerus atas jasa, produk, manusia, proses, dan lingkungannya (Gaperz, 2002). Total quality management juga diartikan sebagai strategi manajemen yang ditujukan untuk menanamkan kesadaran kualitas pada semua proses dalam perusahaan. Strategi tersebut adalah pendekatan secara keseluruhan yang berkaitan dengan pelaksanaan gagasan, perencanaan, dan eksekusi sebuah aktifitas dalam kurun waktu tertentu (Mulyadi, 1998). Kualitas tersebut bukan hanya tentang kualitas produksi. Akan tetapi, juga banyak aspek atau banyak arti tentang kualitas. Makna kualitas dapat dilihat dari berbagai sudut pandang. Produk kualitas dapat dilihat dari segi pendidikan. Pendidikan memiliki dua produk, yaitu pelajar atau peserta didik dan pelajarannya. Kualitas dapat 
diartikan sebagai pemenuhan kebutuhan pelanggan dengan selera mereka.

Kata manajemen memiliki arti, bahwa kualitas ini harus ada yang mengaturnya, dikembangkan dan dijaga dengan berbagai macam strategi. Manajemen tersebut mengatur orang yang ada di dalamnya agar mengarah ke tujuan bersama. Manajemen kualitas berfungsi mengendalikan agar tidak ada produk yang cacat. Manajemen juga memiliki peran perbaikan produk karena di dalamnya terdapat sistem pengendalian.

\section{Konsep Total Quality Management}

Total quality management bertujuan untuk terus-menerus meningkatkan nilai yang diberikan bagi pelanggan dengan biaya penciptaan nilai yang lebih rendah daripada nilai suatu produk. Konsep total quality management memerlukan komitmen semua anggota organisasi terhadap perbaikan seluruh aspek manajemen organisasi. Pada dasarnya konsep TQM mengandung tiga unsur, yaitu (Nasution, 2015):

a. Strategi nilai pelanggan, yakni manfaat yang didapat pelanggan atas penggunaan barang atau jasa dari pengorbanan pelanggan untuk memperolehnya. Strategi ini merupakan perencanaan bisnis untuk memberi nilai tambah termasuk karakteristik produk, cara penyampaian, pelayanan dan sebagainya. b. Sistem organisasional, yakni berfokus pada penyediaan nilai bagi pelanggan. Sistem ini mencakup tenaga kerja, material, mesin atau teknologi proses, metode operasi dan pelaksanaan kerja, aliran proses kerja, arus informasi dan pembuatan keputusan.

c. Perbaikan kualitas untuk menghadapi lingkungan eksternal yang selalu berubah, terutama perubahan selera pelanggan. Konsep ini menuntut adanya komitmen untuk melakukan pengujian kualitas produk secara kontinu sehingga dapat memuaskan pelanggan.

\section{Prinsip Total Quality Management}

Total Quality Management merupakan suatu sistem yang berupaya mewujudkan standard kualitas kelas global, oleh karenanya diperlukan suatu sistem nilai dalam menerapkan total quality management di dalam organisasi atau perusahaan. Hensler dan Brunell dalam Nasution (2015) menjelaskan ada empat prinsip utama dalam total quality management, yaitu:

a. Kepuasan Pelanggan

b. Respek Terhadap Setiap Orang

c. Manajemen Berdasarkan Fakta

d. Perbaikan Berkesinambungan

Prinsip-prinsip di atas menjelaskan apa dan bagaimana total quality management diterapkan dalam perusahaan. Goetsch dan Davis dalam Tjiptono \& Diana (2005) menjelaskan ada sepuluh komponen terkait 
penerapan TQM di suatu organisasi, yaitu: (1) fokus pada pelanggan, (2) obsesi terhadap kualitas, pendekatan ilmiah, (4) komitmen jangan panjang, (5) kerjasama tim, (6) perbaikan sistem secara berkesinambungan, (7) pendidikan dan pelatihan, (8) kebebasan yang terkendali, (9) kesatuan tujuan, (10) adanya keterlibatan dan pemberdayaan karyawan.

Implementasi total quality management harus menggunakan metode-metode yang terarah sehingga tujuan perusahaan dapat tercapai. Proses ini berlangsung secara berkesinambungan dan terus-menerus dengan melibatkan semua sumber daya perusahaan. Subsistem-subsistem perusahaan saling bekerjasama mencapai perbaikan berkesinambungan. Dalam upaya perbaikan tersebut, perusahaan memberikan edukasi dan pengembangan diri bagi sumber daya yang terlibat di dalam perusahaan.

\section{Manajemen Operasional}

Manajemen operasional merupaka n serangkaian aktifitas yang menghasilkan nilai dalam bentuk barang dan jasa, dimana input diubah menjadi output (Haizer \& Rander, 2014). Manajemen operasional adalah penerapan ilmu manajemen untuk mengatur kegiatan operasi agar dapat dilakukan secara efektif dan efisien. Fungsi tersebut mengintegrasikan berbagai sumber daya secara efisien dalam rangka mencapai tujuan perusahaan. Serangkaian proses operasional dapat menciptakan atau menambah kegunaan barang atau jasa untuk memenuhi kebutuhan manusia.

\section{Metode Penelitian}

Penelitian ini menggunakan pendekatan kualitatif deskriptif. Kualitatif merupakan penelitian yang menggunakan data berupa wawancara, observasi, catatan lapangan, dan dokumen pribadi, serta dokumen resmi yang lain. Penelitian kualitatif merupakan serangkaian kegiatan yang meliputi proses penyaringan data atau informasi. Proses tersebut bersifat sewajarnya terhadap suatu masalah dalam sebuah kondisi, aspek atau bidang tertentu pada objeknya (Nawawi, 1994). Penelitian kualitatif juga bergantung pada pengamatan manusia, kawasannya sendiri, dan berhubungan dengan orang-orang tersebut dalam bahasanya dan istilahnya (Moleong, 2004).

Proses pengumpulan data melalui terjun langsung wawancara dan observasi informan diharapkan mampu memberikan pemahaman tentang fenomena atau studi kasus yang sedang dialami oleh subyek penelitian. Fenomena atau studi kasus tersebut dapat berupa perilaku, persepsi, bahasa pada suatu konteks khusus yang alamiah. Dalam penelitian ini, peneliti menggunakan teori-teori yang sudah menjadi bagian dari ilmu manajemen. Teori-teori tersebut berfungsi untuk menjelaskan dan mengungkap fenomena atau studi kasus yang berkaitan dengan Total Quality Management (TQM) dalam 
manajemen operasional di Intanaya Tour and Travel Cabang Surabaya.

Selain itu, penelitian ini menggunakan metode deskriptif digunakan untuk mendeskripsikan segala hal yang telah terjadi. Hal tersebut bertujuan untuk mendapatkan semua fakta yang berkaitan dengan Total Quality Management (TQM) dalam Manajemen Operasional di Intanaya Tour and Travel Cabang Surabaya.

\section{Hasil dan Pembahasan}

\section{Konsep Total Quality Management di Intanaya Tour and Travel}

Pada dasarnya konsep total quality management mengandung tiga unsur. Pertama, strategi nilai pelanggan. Strategi ini merupakan perencanaan bisnis untuk memberikan nilai bagi pelanggan termasuk karakteristik produk, cara penyampaian, pelayanan dan sebagainya. Dalam Intanaya Tour and Travel dijelaskan bahwa, untuk mengetahui kualitas pelayanan di Intanaya Tour and Travel, muthawwif secara langsung menanyakan kepada jamaah tentang layanan yang sudah diberikan selama perjalanan ibadah umroh. Selain itu, Intanaya Tour and Travel juga menggunakan kuesioner. Ini bertujuan mengetahui respon jamaah terhadap pelayanan yang telah diberikan. Intanaya Tour and Travel sendiri mempunyai perencanaan bisnis, berupa pemetaan terhadap nilai layanan yang akan diberikan kepada jamaah. Ini menunjukkan Intanaya Tour and Travel melaksanakan strategi nilai pelanggan.
Kedua, sistem organisasional, yang berfokus pada penyediaan nilai bagi pelanggan. Sistem ini mencakup tenaga kerja, material, mesin atau teknologi proses, metode operasi dan pelaksanaan kerja, aliran proses kerja, arus informasi, dan pembuatan keputusan. Data di lapangan menunjukkan bahwa Intanaya Tour and Travel menjaga kualitas dari sisi komunikasi dengan para jamaah, sebelum atau sesudah kegiatan ibadah umrah terlaksana. Karyawan membuat planning harian, dan pimpinan mengawasi kinerja para karyawannya secara langsung. Dari fakta tersebut dapat diketahui bahwa Intanaya Tour and Travel menerapkan sistem organisasional yang berfokus pada penyediaan nilai bagi pelanggan. Sebagai bentuk usaha jasa, pengendalian proses layanan, SDM, proses kerja dan arus informasi dilakukan melalui komunikasi, dan pada titik ini Intanaya Tour and Travel menunjukkan sistem operasi komunikasi yang telah berjalan stabil. Ketiga, perbaikan kualitas. Hal ini diperlukan untuk menghadapi lingkungan eksternal yang selalu berubah, terutama perubahan selera pelanggan. Intanaya Tour and Travel juga memiliki sistem perbaikan, melalui perencanaan perbaikan oleh manager operasional. Dengan adanya perencanaan diharapkan lebih maksimal dalam melayani Jamaah yang menggunakan jasa mereka. 
2. Prinsip Total Quality Management di Intanaya Tour and Travel

Hensler dan Brunell menjelaskan ada empat prinsip utama dalam total quality management, yaitu $:^{5} \quad 1$ ) Kepuasan pelanggan. kepuasan bisa diartikan sebagai upaya pemenuhan sesuatu atau membuat sesuatu memadai. Perusahan akan berusaha untuk memenuhi kebutuhan konsumen dengan cara menyediakan produk atau jasa. ${ }^{6}$ 2) Respek terhadap setiap orang, sumber daya manusia merupakan asset perusahaan. Setiap individu memiliki kapasitas dan kapabilitas yang berpotensi untuk meningkatkan kemajuan perusahaan. $^{7}$ 3) Manajemen berdasarkan fakta, setiap pengambilan keputusan harus didasarkan atas data atau fakta di pasar konsumen. Perbaikan tidak bisa dilakukan secara bersamaan di semua bidang perusahaan. $^{8} \quad$ 4) Perbaikan berkesinambungan, pemantauan terhadap perubahan customer, proses ini dilakukan untuk memuaskan kebutuhan konsumen. ${ }^{9}$

Dalam menjalankan prinsip total quality management, Intanaya Tour and Travel selalu menjaga kepuasan pelanggan. Hal ini dilakukan dengan mengandalkan peran penting customer service dalam memahami jamaah, menyampaikan informasi kepada jamaah dengan baik dan memberikan pelayanan terbaik kepada jamaah. Hal

\footnotetext{
${ }^{5}$ M. Nur Nasution, Manajemen Mutu Terpadu, (Bogor: Ghalia Indonesia 2015), hal. 26

${ }^{6}$ Mulyadi, Total Quality Management, (Yogyakarta : Aditya Media Yogyakarta : 1998), hal. 17
}

ini dilakukan dengan cara menjaga komunikasi dengan jamaah, melakukan evaluasi dan memberikan kepercayaan kepada jamaah.

Intanaya Tour and Travel juga memberikan kebebasan berpendapat kepada seluruh karyawannya. Contohnya kebebasan berpendapat saat rapat, serta mengoptimalkan perkembangan, kemajuan teknologi, dan kondisi eksternal dalam mengambil sebuah keputusan. Selain itu, Intanaya Tour and Travel juga melakukan perbaikan dengan cara meminta testimoni, kritik dan saran kepada jamaah baik yang lama maupun baru.

Dari deskripsi di atas dapat dilihat Intanaya Tour and Travel memiliki prinsip total quality management, meliputi kepuasan pelanggan, respek terhadap setiap orang, manajemen berdasarkan fakta, dan perbaikan kesinambungan.

3. Tujuan dan manfaat Total Quality Management di Intanaya Tour and Travel

Kualitas terbaik dapat dihasilkan dari upaya kemampuan manusia, proses, dan lingkungan. Cara terbaik untuk mencapai hal tersebut adalah dengan cara menerapkan total quality management. Manfaat dari total quality management (Nurl \& Wahyuni, 2011) di antaranya: 1) membangun mutu

\footnotetext{
${ }^{7}$ Ibid, hal. 17

${ }^{8}$ Henslerr dan Brunell dalam Sudirman, Total Quality Management untuk Wakaf, (Malang: UIN Maliki Press, 2013), hal. 85

${ }^{9}$ Mulyadi, Op.cit, hal. 18
} 
prosesi produksi dalam menghasilkan produk yang $100 \%$ bebas cacat; 2) membantu lembaga dalam menemukan kesalahan atau kegagalan sebelum menjadi musibah bagi lembaga tersebut; 3) menghasilkan produk sesuai keinginan pelanggan, agar produk tersebut bisa memberikan manfaat kepada pengguna; 4) membantu lembaga menemukan datadata produksi yang salah.

Tujuan penerapan Total Quality Management di Intanaya Tour and Travel adalah untuk meningkatkan kepuasan jamaah. Intanaya Tour and Travel lebih terfokus pada pelayanan yang diberikan kepada jamaahnya, yaitu rasa empati dan perhatian kepada jamaah. Selain itu, visi misi Intanaya Tour and Travel berfokus pada pemaknaan terhadap ibadah umroh, agar para jamaah ketika selesai umroh bisa mengalami perubahan pada dirinya. Dengan demikian jamaah mendapat manfaat berupa peningkatan spiritulitas dan perubahan perilaku.

Dari uraian di atas dapat disimpulkan bahwa manfaat total quality management di Intanaya Tour and Travel yaitu memberikan pelayanan travel yang berkualitas serta peningkatan nilai spiritualitas kepada para jamaah. Hal ini sejalan dengan teori total quality management yang membangun mutu proses produksi untuk menghasilkan produk yang bebas cacat, pelayanan maksimal pada setiap proses serta meningkatkan kepuasan pengguna.
4. Fase implementasi Total Quality Management di Intanaya Tour and Travel

Fase implementasi total quality management menjadi tiga fase (Tjiptono \& Anastasya, 2003), yaitu persiapan, perencanaan dan pelaksanaan.

a. Fase Persiapan

Fase ini membutuhkan komitmen penuh dari manajemen puncak atas waktu dan sumber data yang dibutuhkan. Langkah-langkahnya antara lain: 1) membentuk Total Quality Steering Committee; 2) membentuk tim; 3) pelatihan Total Quality Management; 4) menyusun pernyataan visi dan prinsip sebagai pedoman; 5) menyusun tujuan umum; 6) komunikasi dan publikasi; 7) identifikasi kekuatan dan kelemahan; 8) identifikasi pendukung dan penolak; 9) memperkirakan sikap karyawan; 10) mengukur kepuasan pelanggan. Di Intanaya Tour and Travel, steering committee di bawah kendali manajer operasional, yang mendelegasikan fungsi operasional kepada salah satu staf yang dianggap mampu. Tim kontrol kualitas pelayanan terdiri dari supervisor, customer service, driver, web, IT, perlengkapan dan handel, surat menyurat dan input data sistem. Masing-masing peran di atas mempunyai tugas dan fungsinya untuk menjaga kualitas pelayanan. Pelatihan juga dilakukan baik berupa pelatihan 
implementasi TQM maupun pelatihan oleh Kementerian Agama, sehingga mampu meningkatkan pengetahuan dan skill tentang cara menghadapi jamaah yang baik.

Selain itu, Intanaya Tour and Travel juga merumuskan visi misi serta tujuan umum dalam menjalankan jasanya. Visi misi ini lebih fokus pada peningkatan kualitas pelayanan, serta dikomunikasikan di semua level dari pimpinan ke karyawan. Pimpinan selalu turun langsung mengontrol kinerja karyawan setiap hari. Bentuk komunikasi ini membuat karyawan bisa lebih dekat dan nyaman ketika berinteraksi dengan pimpinan, sehingga ketika ada permasalahan karyawan bisa terbuka.

Intanaya Tour and Travel juga menggali respon jamaah atas layanannya dengan menggunakan angket dan dialog langsung. Bentuk instrument pertanyaan yang diberikan seperti contohnya tentang bagaimana pelayanan di hotel, pelayanan bimbingan oleh mutowif, kenyamanan perjalanan di pesawat. Dengan instrumen pertanyaan di atas Intanaya Tour and Travel mampu mendapatkan informasi tentang kekurangan dan kelebihan pelayanan yang telah diberikan sehingga dapat dilakukan perbaikan.

b. Fase Perencanaan
Fase perencanaan yaitu, merencanakan pendekatan implementasi, kemudian menggunakan siklus PDCA (Plan, Do, Check, and Adjust), identifikasi proyek, komposisi tim, dan pelatihan tim. Intanaya Tour and Travel membuat perencanaan tahunan dan menyampaikan kepada karyawan, memberikan arahan kepada karyawan untuk membuat perencanaan masing-masing, memberikan tugas, melakukan control dan evaluasi kepada setiap karyawan. Hal ini dilakukan untuk mengontrol kinerja agar sesuai dengan tugasnya masing-masing dan tetap terjaga kualitas kerjanya. Intanaya Tour and Travel juga membuat variasi paket atau jenis layanan untuk jamaah dengan harga serta fasilitas yang berbeda. Tujuannya agar jamaah bisa memilih paket sesuai kebutuhan dan kapasitas masing-masing. Dengan demikian Intanaya Tour and Travel bisa mendapat jamaah sesuai target.

c. Fase Pelaksanaan

Fase pelaksanaan yaitu, penggiatan tim, umpan balik dari pelanggan, umpan balik dari karyawan, dan memodifikasi infrastruktur. Inatanaya Tour and Travel melakukan implementasi berupa sistem evaluasi dan pemetaan kepuasan para jamaah yang disampaikan kepada tim manajemen. Tim lalu 
mengidentifikasi kelemahan dan kelebihan dari pelayanan yang ada, di antaranya berkaitan dengan kenyamanan hotel, pelayanan muthowif, dan tingkat kualitas proses dari pemberangkatan hingga pemulangan. Dengan adanya data ini Intanaya Tour and Travel mampu mengevaluasi kualitas yang diberikan kepada jamaah.

Intanaya Tour and Travel juga melakukan perubahan prosedur untuk meningkatkan pelayanan terhadap jamaah. Langkah yang diambil misalnya berupa pergantian staf, pengembangan media publikasi dengan situs web, penambahan fasilitas transportasi untuk operasional dan sistem penyimpanan perlengkapan di gudang. Tujuannya adalah memenuhi kebutuhan jamaah, menyesuaikan dengan perkembangan zaman dan memenuhi kebutuhan operasional kantor. Dengan perubahan ini, Intanaya Tour and Travel bisa memberikan pelayanan yang terbaik, fasilitas yang memadai, dan melakukan promosi secara efektif, sehingga mampu menjaga kualitas dan tetap bersaing.

\section{Fungsi Manajemen Operasional di Intanaya Tour and Travel}

Manajemen operasional yang efektif dan efisien akan tercapai dengan menerapkan fungsi manajemen operasional sebagai berikut (Natalia, 2016): 1) perencanaan operasional, meliputi perencanaan kapasitas produksi, lokasi, susunan tata ruang (layout), kualitas dan metode produksi yang digunakan; 2) penskedulan operasional, meliputi penjadwalan produksi pada waktu tertentu serta produk atau jasa apa yang akan dijual, sehingga memudahkan dalam menyediakan sumber daya yang akan diproses; 3) pengawasan operasional, menyangkut sistem pengendalian mutu dan manajemen material seperti transportasi, pergudangan, dan inventori. Kegiatan kontrol operasional diperlukan untuk memonitor kinerja dengan membandingkan hasil dan rencana.

Intanaya Tour and Travel memiliki beberapa sistem perencanaan operasional, yaitu pemetaan internal dan eksternal. Pemetaan internal di antaranya budgetting, pengelolaan SDM, pemetaan waktu, dan pemetaan fasilitas yang akan diberikan kepada jamaah. Pemetaan eksternal, di antaranya pemetaan karakteristik serta kemempuan membeli para jamaah, pemetaan harga pesaing, dan legalitas jasa. Intanaya Tour and Travel memetakan lokasi, dan yang dipilih yakni Surabaya, Sidoarjo, Lumajang dan Solo. Empat lokasi tersebut dipilih karena memiliki karakteristik masyarakat yang relijius dan padat penduduk. Ini memudahkan aksesibilitas calon jamaah ke pelayanan Intanaya Tour and Travel. Penataan ruang kantor juga baik, disesuaikan dengan kebutuhan karyawan serta jamaah, di antaranya 
terdapat fasilitas AC dan tempat duduk berupa sofa agar calon jamaah merasa nyaman.

Intanaya Tour and Travel memiliki skedul dalam menjalankan operasional pelayanan jasa travel. Waktu enam bulan dibutuhkan dalam mempersiapkan jadwal keberangkatan umroh, dengan rata-rata dua kali keberangkatan dalam satu bulan, menyesuaikan dengan jadwal di Makkah serta kapasitas sumber daya manusia yang tersedia. Intanaya Tour and Trevel juga melakukan pengawasan kepada para karyawan untuk mengetahui kualitas layanan perusahaan, diantaranya dengan kontrol terhadap customer service, web IT (publikasi), administrasi, realisasi kualitas dan kuantitas paket yang diterima jamaah serta kontrol terhadap penyimpanan barang-barang di gudang. Kontrol dijalankan secara menyeluruh agar produk dan layanan yang diberikan kepada calon jamaah tetap terjamin kualitasnya.

\section{Kesimpulan}

Penelitian ini menunjukkan bahwa Intanaya Tour and Travel telah mengadopsi konsep dan mengimplementasikan Total Quality Management dalam manajemen operasional layanan usahanya. Pokokpokok strategi meliputi strategi nilai pelanggan, sistem organisasional serta perbaikan kualitas telah berjalan secara konsisten dan menunjukkan adanya peningkatan jumlah jamaah yang menggunakan jasanya.
Selain itu, prinsip-prinsip TQM juga telah berjalan dengan baik meliputi kepuasan pelanggan, respek terhadap setiap orang, manajemen berdasarkan fakta dan perbaikan kesinambungan di semua lini proses. Ini menghasilkan manfaat antara lain proses produksi produk/layanan bebas cacat, identifikasi kesalahan sejak dini, operasional layanan dan produk sesuai keinginan pelanggan serta dapat menemukan data-data operasional yang salah. Implementasi TQM dalam manajemen operasional Intanaya Tour and Travel meliputi persiapan, perencanaan dan pelaksanaan dengan mengedepankan komunikasi produktif yang melibatkan semua stakeholder terkait mulai pimpinan, karyawan, pengguna jasa hingga pihakpihak terkait lainnya.

\section{Daftar Pustaka}

Wahyu, Ariani Dorothea. 2003. Manajemen Kualitas Pendekatan Sisi Kualitatif. (Jakarta : Ghalia Indonesia).

Gaspersz. 1998. Manajemen Produktivitas Total. (Jakarta : Gramedia Pustaka Utama).

Sallis, Edward. 2006. Total Quality Management in Education; Manajemen Mutu Pendidikan. (Yogyakarta : IRCiSoD, Cet. IV).

Suyitno. 2016. Peningkatan Sumber Daya Manusia Melalui Penerapan Total Quality Management. (Jurnal Akuntansi, Ekonomi, dan Manajemen Bisnis, Vol.4, No.2).

Mulyadi. 1998. Total Quality Management. (Yogyakarta : Aditya Media Yogyakarta).

Carolina. 2012. Pengaruh Penerapan Total Quality Management (TQM) Dan Komitmen Organisasi Terhadap Kinerja Perusahaan Dengan Budaya Organisasi Sebagai Variabel Moderasi (Survei Pada Perusahaan Manufaktur Di Jawa Barat Yang Listing Di BEI). (Jurnal Akuntansi, Vol.4, No.2).

Lubis, Alfi Syahri. 2017. Pengaruh Kualitas Pelayanan (Service Quality) Terhadap Kepuasan Pelanggan PT. Sucofindo Batam. (Jurnal Administrasi, Vol.1, No.2).

Hastawi, Edwin. Manajemen Operasional Paket Wisata City Tour Surakarta di PT. Kirana 
Surya Gemilang Yogyakarta (Studi Kasus Rombongan Ikatan Wanita Bank Yogyakarta). (Jurnal Pariwisata Terapan, Vol.1, No.2).

Munizu. 2010. Praktik Total Quality Management (TQM) dan Pengaruhnya Terhadap Kinerja Karyawan (Studi Pada PT Telkom Tbk. Cabang Makassar). (Jurnal Manajemen dan Kewirausahaan, Vol 12, No.2).

Assauri. 2016. Manajemen Operasi Produksi Pencapaian Sasaran Organisasi Berkesinambungan. (Jakarta: Rajawali Pers).

Sularso dan Murdijanto. 2014. Pengaruh Penerapan Peran Total Quality Management Terhadap Kualitas Sumber Daya Manusia. (Jurnal Manajemen dan Kewirausahaan Vol 6, No.1).

Ebert dan Griffin dikutip dalam Natalia. 2016. Analisis Pengelolaan Operasional dan Total Quality Management di CV. Star Digital Printing. (Jurnal Agora, Vol.4, No.2).

Flippo dan Mappasiara. 2018. Manajemen Strategik dan Manajemen Operasional serta Implementasinya pada Lembaga Pendidikan. (Jurnal Idaarah, Vol. 2, No. 1).

Tjiptono dan Diana. 2002. Total Quality Management. (Yogyakarta : Penerbit Andi).

Henslerr dan Brunell dalam Sudirman. 2013. Total Quality Management untuk Wakaf. (Malang: UIN Maliki Press).

Natalia. 2016. Analisis Pengelolaan Operasional dan Total Quality Management di CV. Star Digital Printing. (Jurnal Agora, Vol.4, No.2).

J.Moleong, Lexy. 2004. Metode Penelitian Kualitatif. (Bandung: Remaja Rosdakarya).

Martoyo. 2010. Statistik Sosial. (Yogyakarta: Gaya Media).

Bungin, Burhan. 2001. Metodologi Penelitian Sosial. (Surabaya: Airlangga Unniversity Press).

Prastowo. 2016. Metode Penelitian Kualitatif dalam Perspektif Rancangan Penelitian. (Yogyakarta: Ar-Ruzz Media).

Sugiyono. 2013. Metode Penelitian Pendidikan Pendekatan Kuantitatif Kualitatif dan R\&D. (Bandung: Afabeta).
Putra dan Lisnawati. 2012. Penelitian Kualitatif Pendidikan Agama Islam. (Bandung: PT Remaja Rosdakarya).

Giles, Tuner J.C. 1985. Intergroup Behaviour. (Oxford : Basil Blacwell).

Harabab, Syarif Sovyan. 2004. Analisis Kritis Tentang Laporan Keuangan. (Jakarta: PT. Raja Grafindo Persada). 